JOURNAL OF PUBLIC HEALTH FOR TROPICAL AND COASTAL REGION

(JPHTCR)

Journal homepage: http:/ejournal2.undip.ac.id/index.php/jphtr/index

ISSN : 2597-438

\title{
The Analysis Of Lamongan Toddler Nutrition Care (PELITA LA) Program in Dradah Health Center Lamongan
}

\author{
Aulia Firda Rahmawati ${ }^{\star *}$, Besar Tirto Husodo', Novia Handayani ${ }^{1}$ \\ 1. Department of Health Education and Behavioral Sciences, Faculty of Public Health, Diponegoro \\ University,Semarang, Indonesia \\ *Corresponding author, Email: auliafirdarahmawati@students.undip.ac.id
}

\begin{abstract}
Introduction: The prevalence of stunting in Lamongan is reaching $35,5 \%$, so the efforts to reduce the prevalence of stunting in Lamongan was implementing the Lamongan Toddler Nutrition Care program. There is no evidence of the successes of that program. The purpose of this study is to analyze the process of the Lamongan Toddler Nutrition Care (PELITA LA) program on stunting in Lamongan, East Java.

Methods: This research uses qualitative methods with in-depth interview data collection techniques and includes descriptive research. The sample of this research is 5 respondents who are selected using purposive sampling. This research has been approved as ethical by the ethics committee. The process of data analysis in this study starts by collecting data from the interview results and then reducing the data that has been generated. After that, the data are presented and concluded.

Results: The results showed that not all the the village health workers had received training, the infrastructure was insufficient and there were no program implementation guidelines so can influence prevalence stunting. However, the process of management like planning, organizing, actuating, and controlling have been good. In another statement about the successes of the program is decreasing the prevalence of the stunting and increasing the participants' knowledge but the participants are not measured with certainty to find out their knowledge.

Conclusion: The conclusion is the nutrition care program for Lamongan toddlers at the Lamongan Health Center has not been running optimally because the input and output aspects have not been going well.
\end{abstract}

Keywords: nutrition care, stunting, toddler. 


\section{Introduction}

Stunting prevalence has become a global issue. In 2018, the WHO set a target for the prevalence of stunting at $20 \%$. However, the stunting prevalence in Indonesia is still far below the WHO target's amount at $30.8 \% .^{1}$ In the hope of preventing and reducing stunting in Indonesia, the government has appointed 100 priority districts for stunting. One of the districts included in the stunting priority is Lamongan regency. The prevalence of stunting in Lamongan in 2013 was $48.87 \%$ and decreased in 2018 to $35.5 \% .^{2}$

Stunting is caused by insufficient nutritional intake, frequent illness or infection, and low birth weight. Based on Uliyana's research, it is stated that there was a significant effect between nutritional intake and the prevalence of stunting. ${ }^{3}$ Nutritional intake in toddlers is related to maternal or family parenting, and information about toddler nutrition. Maternal parenting is related to exclusive breastfeeding, provision of complementary foods, and hygiene. ${ }^{4}$ Complementary foods are given after the infant is 6 months old. Diverse complementary foods can reduce the risk of stunting in toddlers. ${ }^{5}$ Meanwhile, information about toddler nutrition can be provided through offline and online counseling. Providing nutritional information to mothers of toddlers can increase mothers' knowledge of toddler nutrition. ${ }^{6}$

Stunting is a prolonged growth disorder and nutritional insufficiency in toddlers. Therefore, stunting has a dangerous impact. The impact of stunting is divided into two; short-term and longterm. ${ }^{4}$ The short-term impact includes the damaged brain development which results in impaired intelligence, in addition to physical growth disorders and metabolic disorders in the body. Whereas the long term-impact caused by stunting is a decrease in some abilities and immunity including cognitive abilities and learning achievement, immunity thus getting sick easily, as well as a high risk for diabetes, heart and blood vessel disease, cancer, stroke, and disabilities in old age. ${ }^{7}$ These things will certainly disturb the quality, productivity, and competitiveness of toddlers who will become future leaders of Indonesia. ${ }^{8}$

Handling stunting requires multisectoral roles. The government made a strategy for accelerating nutrition in the National Medium Term Development Plan 2015-2019. The plan mentioned several interventions to prevent stunting; health promotion, reinforcing community-based health efforts, improving nutrition, improving the quality of health services, strengthening and monitoring regulations, and building up cross-sectoral roles. The targets of these interventions are pregnant women, mothers of toddlers, young women, and also prospective brides. ${ }^{9}$

Lamongan regency has a program to accelerate stunting reduction. The Lamongan Toddler Nutrition Care Program is a program that aims to reduce the prevalence of stunting in Lamongan regency. The specific objective of this program is to provide special guidance to cadres and mothers of toddlers regarding complementary feeding and the recipes of balanced nutrition to achieve public awareness about nutrition for toddlers. The activities included in this program are cooking class, health promotion, PMT distribution, as well as community feeding center. This program is aimed at mothers of toddlers, especially those with stunting children, pregnant women with chronic energy deficiency (CED mothers), and women with high-risk pregnancies in Lamongan. This program was initiated by the Lamongan Health Office and the health centers as the implementer and assisted by health workers. ${ }^{10}$ Dradah Health Center is one of the health centers that implement this program. However, Dradah Health Center is the top 5 contributors to stunted toddlers during the last two years. Based on this information, the researchers researched on the Evaluation of the Lamongan Toddler Nutrition Care Program (PELITA LA) Implementation in Lamongan regency in the work area of Dradah Lamongan Health Center.

\section{Methods}

This research is qualitative descriptive research with a case study approach. In this study, 5 research subjects 
are the program implementers, namely health workers. The research subjects were obtained using the purposive sampling method.

Validity testing was achieved with 7 triangulation subjects, including 5 program participants and 1 person in charge (PIC) of the program at the Health Center level and $1 \mathrm{PIC}$ at the Health Office level. Reliability testing was conducted by auditing the data. Research data collection was carried out by conducting in-depth interviews. This study has got ethical clearance from Faculty of Public Health Diponegoro University with the number of: No. 168/EA/KEPK-FKM/2020.

\section{Results Input}

Man

In this program, the program implementers are 5 health workers. Each cadre has their respective duty; as a cook, a facility and infrastructure manager, and a shopper. Based on interviews with the main informant, 5 health workers are sufficient in actuating the program. The backgrounds of each cadre are different, 1 bachelor graduate, 1 junior high school graduate, and 3 high school graduates.

In supporting the quality of the resources, training is needed. The training aims to increase skills and knowledge. This is under Lismawati's research that training and counseling have an effect on increasing the knowledge and the ability of health workers in carrying out activities. ${ }^{11}$ However, the intensity of training received by the health workers did not increase their knowledge. ${ }^{12}$ The training was about nutrition for toddlers, clean and healthy life behavior (CHLB), and integrated services post. Training on nutrition for toddlers and CHLB was provided by the Lamongan District Health Office by sending a maximum of 2 health workers from each health center as a representative. Meanwhile, the training given by the health center was carried out during integrated services posts and coaching sessions. However, not all health workers attended the training provided by the health center for certain reasons, thus the training did not reach its full potential which is to deliver the needed information to all health workers.

"There is no structure for this
program. The division of duties is 1
person in the cooking division, 1
person in the shopping division, 2
people are in the facility and
infrastructure division, and the rest
helps the cook."

Based on the information gained from the PIC of the program at the health center, this causes measurement errors in the measurement of toddlers resulting in a high prevalence in Dradah health center.

"We did not receive specialized
training for this program.
However, the health office always
provides training for health
workers. Usually, the
representative who takes part in
the training will later share their
knowledge with other health
workers during the integrated
services post or just give out the
files or books obtained from the
training. The training itself is
regarding measuring and
weighing children in the integrated
services post, emotional
demonstration, CHLB material,
and also communication training.
There was also a training session
from Padjajaran University on
stunting last year." IN

Money

Money (funds) is one of the resources needed in every program and activity. ${ }^{13}$ Without funds, a program or activity cannot be run. This is consistent with Azwar's statement that a health program must 
have sufficient funds to carry out the program well. The evaluation of the implementation of the funding aspect aims to see the extent to which the required sources of funds run smoothly.

In the light of the research results, the PELITA program receives health assistance funds of 2,700,000 Rupiah/year and village funds of 400,000 Rupiah/year. For that reason, all activities are covered by HAF and village funds. Participants who attend the program are free of charge. Besides, health workers receive incentive funds from the health office amounted to 200,000 Rupiah/year.

"Health assistance funds and village funds. The health assistance funds (HAF) that we received last year was around 2.500.000 Rupiah, I forgot the exact amount"

SR

\section{Material}

The implementation of a program must have the infrastructure to support the success of the program. A program that involves a community needs a place to gather and solve problems. The Lamongan Toddler Nutrition Care program does not have a permanent place to host the program yet. Every year, this program usually uses residents' houses with a large yard.

"The infrastructure used to support the PELITA program is incomplete. For instance, we only have a scale. We don't have a measurement instrument for stunted children yet. Additionally, we can borrow a laptop and projector from the health center. We use the village funds to print/photocopy medical prescriptions. Moreover, stove, plates, and spoons are provided by the host."
Method

Methods are guidelines used in carrying out a program so that the program runs smoothly. ${ }^{13}$ The methods or guidelines used are usually in the form of SOPs or regulations. Related to the research results, there is no SOP in this program which regulates the overall execution of this program. This program only has a recipe book that contains the program's objectives and some recipes for complementary foods.

"There is no SOP for this Pelita program. It is more like direct orders from the health office to the health center. After that, the health center will deliver orders to the health workers."

SR

\section{Process}

Planning

The Toddler Nutrition Care program is a program initiated by the Lamongan Health Office. The planning at the health center level is carried out by the PIC of the health center's programs. The source of funds for this program is from HAF (Health Assistance Funds).

"In the early phase of the Pelita program, the planning stage was conducted by the health office regarding costs and also the form of the program. Afterward, our health center was ordered to execute this program. The health center organized the program into POA (plan of action) and set a date for it. Later on, everything was informed to the health workers as implementers. The health workers then coordinated with each other to prepare this program. Some shop, cook, and also prepare the infrastructure. The liaison between the health center and the health workers is usually the head of the workers." 
All programs which are funded by HAF must propose the programs executed in the previous year in the form of a POA so that the funds will be disbursed in the following year. The planning made by the PIC of the program is following the Minister of Health Regulation No. 44 of 2016 regarding Health Center Management Guidelines. ${ }^{14}$ On the other hand, the planning of the program itself is made by the health workers before the activities at the integrated services post. If the faceto-face discussion is not finished yet, it will be continued via WhatsApp.

The planning carried out by the health workers is only regarding the food menu to be practiced and the division of tasks. Health promotion materials are prepared by the PIC of the health center's program. The material presented is about nutrition, CHLB, and also stunting. The duration of the program is decided by the health center in each region. In the Lamongan Toddler Nutrition Care program, the method used is counseling or lectures and direct practice. The target of this program is stunting mothers of toddlers.

\section{Organizing}

Organizing is a process of grouping people, tools, tasks, responsibilities, or authority in a way as to create organizational management that can be arranged as a unit to achieve predetermined goals. ${ }^{15}$

Referring to the research results, the Lamongan Toddler Nutrition Care program does not have an organizational structure in both the health center and the health office. Even though they do not have a tangible organizational structure, the health workers have carried out an organizational function by dividing their tasks, such as cooking, shopping, and preparing the facilities and infrastructure. Routine meetings to discuss the implementation of the Lamongan Toddler Nutrition Care program are held at the integrated services post to make it easier for all parties.

\section{Actuating}

The Lamongan Toddler Nutrition Care program has several activities; cooking class, health promotion, PMT distribution, and community feeding center. In Dradah Health Center, activities for cooking class, health promotion, and PMT distribution have been conducted. The community feeding center, however, has not been actuated because they are considered similar to the implementation of the integrated services posts so it is not much useful. Cooking class activities, along with health promotion activities, were carried out for 12 days. PMT distribution is executed during integrated services post. The toddler nutrition care program is a form of intervention from the National Medium Term Development Plan 2020 regarding the improvement of community nutrition, focusing on accelerating the reduction of stunting by increasing the effectiveness of specific interventions as well as expanding and reinforcing sensitive interventions in an integrated manner. $^{9}$

Specific stunting interventions are including the adequacy of food and nutrition intake; feeding, caring, and parenting; and the treatment of infections/diseases which is provided through this program. Another study that strengthens the effect of specific nutrition interventions, that is parenting on stunting, has shown that there is indeed a relationship between parenting styles and the prevalence of stunting. ${ }^{16}$

"The problem appears when a toddler who is participating in the program is not behaving well. Thus, some mothers of the toddler are forced to leave in the middle of an activity." 


Controlling
The controlling process
referred to in this research is
monitoring and evaluation.
Controlling is the final process in a
program by ensuring that all activities
that are carried went as planned. ${ }^{17}$

"The evaluation and monitoring
of the program discuss how the
program went, whether the
recipe could be easily
understood by the participants,
and checked the attendance of
the mothers with stunted
children. We discussed it during
the evaluation. To monitor the
stunted toddlers, we took a look
at the records from the integrated
services post. The health
workers always record the
growth of the infants and toddlers
there. After that, a representative
from the health office came to
visit. They gave us new material
sometimes, or just dropped by to
monitor the program."

\section{Output}

Output is an impact resulting from a program. ${ }^{18}$ Based on the results of the research, the output of this program is the indicators of the program's success, including the decreased prevalence of stunting and the increased knowledge of participants. Taken from the research results, the method used by the health workers and the PIC of the program to see an increase in the participants' knowledge is by asking direct questions to the participants. If they can answer the questions then the implementers assume that have achieved their goal of increasing knowledge.

\section{Discussion Input}

Concerning the research results, it can be concluded that 5 health workers are sufficient because all workers are assigned with different tasks. Training has been conducted in Dradah Puskesmas. However, not all health workers have been able to participate in all of the training hence some of the workers have not received proper training. This affects the quality of health workers in carrying out activities.

Although the incentive funds cannot be used to meet the daily needs of the health workers, the funds provided for the PELITA program are quite large, thus the health workers feel that they are content with the funds. Taken from Dian's research, sufficient funds can support the implementation of a program. ${ }^{19}$ Therefore, it can be concluded that the aspect of funding is satisfactory.

In the guidelines stipulated by the Ministry of Health, the implementation of mother and toddler classes require a place, electricity, chairs, tables, practical tools, and a playroom for infants/toddlers. Regarding the results of the research and observation of the facilities and infrastructure not owned by the PELITA program, such as manuals, tables, chairs, and a permanent place. The research by Patemah et al stated that there is no relationship between the adequacy of facilities and infrastructure and the implementation of a program. ${ }^{12}$ This is certainly different from Riska's research which mentioned that there is a relationship between the sufficiency of the facilities and infrastructure and a program's implementation. The facilities and infrastructure of Dradah Health Center are not complete yet. For that reason, it is necessary to develop the infrastructure thus the program can run better.

Due to the absence of guidelines or SOPs, it causes several obstacles, including double jobs, miscommunication, no limitation regarding the form of activities and time, and the need to search for a different menu from the official recipe book because it must be adjusted to the food material in each region. This is per Susanti's research on the implementation of Early Stimulation, Detection, and Intervention of Growth and Development of Children (ESDIGDC) which states that good implementation of a program is supported by guidelines or SOPs. ${ }^{20}$ Referring to the research results, the SOPs or guidelines are not yet available for the PELITA Program. Therefore, the method aspect has not been working well. 


\section{Process}

Based on the data, the planning variables in the Toddler Nutrition Care program are following the related regulations. Therefore, this program is in line with the management function.

Based on the description above, it can be seen that the organizational management function in the Lamongan Toddler Nutrition Care program has been carried out, so the management function operates properly.

Based on the research results, there were obstacles during the program, such as bored and fussy toddlers in the middle of activities. The solution to this problem is to prepare toys to prevent such toddlers. From the statement above, it can be concluded that the implementation of this program has been well because 3 out of 4 programs have been successfully conducted. However, the matter of community feeding center needs to be reviewed again.

Based on the results of the research, the controlling process was carried out when the activities of the PELITA LA program were running, while the evaluation was conducted after the program had ended. The health workers along with the midwives evaluated the program by discussing the shortcomings they have encountered during the program. The evaluation to determine the success of the program is also seen by observing the development of height and weight of the toddlers. In conclusion, the controlling process of the nutrition care program for toddlers is up to the mark.

\section{Output}

It is more accurate to conduct a pretest and a post-test for the participants to make the result more measurable. If it is done verbally like asking direct questions, it is feared that other participants will just repeat the common answer thus resulting in intangible evidence of the increased knowledge. This statement is supported by Padmanabha's research which mentioned that pre-test and post-test are an effective form of evaluation to determine a measurable increase in one's knowledge. ${ }^{21}$ In this program, the post-test does not clearly describe the increase in the participants' knowledge.

In addition, the prevalence of stunting has increased by 5.3\% from August 2019. The increased number is caused by the fact that the program did not run optimally since several aspects of the management did not function well. The human resources were not given proper training, incomplete facilities and infrastructure, and nonexistent SOPs or guidelines. If all three aspects are fulfilled, the program will run well and the prevalence of stunting can be decreased.

\section{Conclusion}

The Lamongan Toddler Nutrition Care (PELITA LA) program in Lamongan regency has not run optimally because the training was only conducted for the representative of the health workers. Moreover, the infrastructure to support the program is incomplete such as a permanent place, chairs, tables, and also SOPs. The result of the absence of SOP is miscommunication and double jobs. The prevalence of stunting and participants' knowledge are the indicators of the success of this program. However, Dradah Health Center did not conduct measurable pre-test and post-test so the participants' knowledge cannot be seen quantitatively. Also, the prevalence of stunting at Dradah Health Center in February 2020 has increased.

To increase the success of the Lamongan Toddler Nutrition Care (PELITA LA) program, it is necessary to provide SOPs as well as measurable pre-post and post-test.

\section{References}

1. UNICEF. Prevalence of Stunting [Internet]. 2017 [cited 2019 Nov 10]. Available from: https://data.worldbank.org/indicator/ sh.sta.stnt.zs

2. Dinas Kesehatan Provinsi Jawa Timur. Hasil Utama Riset Kesehatan Dasar Jawa Timur 2018. Badan Penelitian dan Pengembangan Kesehatan Kementrian Kesehatan Republik Indonesia. Surabaya; 2018.

3. Uliyanti. Faktor yang Berhubungan dengan Kejadian Stunting pada 
Balita Usia 24-59 Bulan. J Vokasi Kesehat. 2017;3(2):1-11.

4. Kementerian Kesehatan RI. Buletin Stunting. 1st ed Vol 301. 2018;116378.

5. Balalian AA, Simonyan $\mathrm{H}$, Hekimian K, Deckelbaum RJ SA. Prevalence and determinants of stunting in a conflict-ridden border region in Armenia - A cross-sectional study. BMC Nutr. 2017;3(1):1-13.

6. Rini RP. Pengaruh Penyuluhan Gizi Terhadap Pengetahuan Ibu Dalam Pemberian Menu Seimbang Pada Balita Di Dusun Jamprit Pundong Bantul Yogyakarta Tahun 2016. Progr Stud Bidan Pendidik Jenjang Diploma Iv Fak IImu Kesehat Univ 'Aisyiyah Yogyakarta 2016. 2016;

7. Kementerian Perencanaan Pembangunan Nasional. Laporan Baseline SDG tentang Anak-Anak di Indonesia. 2017.

8. Kementrian Desa Pembangunan Daerah Tertinggal dan Transmigrasi. Buku Saku Desa dalam Penanganan Stunting. 2017.

9. Bappenas. Rencana Pembangunan Jangka Menengah Nasional 20152019. 2019.

10. Patmawati. Implementasi Program Peduli Gizi Balita Lamongan (PELITA LA) di Puskesmas Lamongan Kecamatan Lamongan Kabupaten Lamongan. J Adm Publik UNESA. 2018;

11. Lismayanti L, Rosidawati I. Pelatihan Bagi Kader Posyandu Penyakit Tidak Menular (PTM). ABDIMAS $J$ Pengabdi Masy. 2018;1(2):63-71.

12. Patemah dkk. Faktor Determinan Pelaksanaan Stimulasi Deteksi dan Intervensi Dini Tumbuh Kembang (SDIDTK) oleh Kader di Wilayah Puskesmas di Kota Malang. J Manaj Kesehat Indones. 2013;1(3):227-34.

13. Fidora S. Evaluasi Pelaksanaan Forum Kesehatan Desa Dalam Mendukung Pelaksanaan Pengembangan Desa Siaga Aktif Di Desa Gulon Kabupaten Magelang. Universitas Diponegoro; 2018.

14. Peraturan Menteri Kesehatan Republik Indonesia Nomor 44 Tahun 2016 Tentang Manajemen
Puskesmas.

15. Arifin S, Rahman F, Wulandari A, Anhar V. Dasar-Dasar Manajemen Kesehahatan. 1st editio. Banjarmasin: Pustaka Banua; 2016. 294 p.

16. Astuti D Kusuma. Hubungan Karakteristik Ibu Dan Pola Asuh Gizi Dengan Kejadian Balita Stunted di Desa Hargorejo Kulon Progo DIY. UMS; 2016.

17. Darmawan SE dkk. Administrasi Kesehatan Masyarakat. Depok: Rajagrafindo Persada; 2016.

18. Azwar A. Pengantar Administrasi Kesehatan. Tiga. Tangerang: Binarupa Aksara; 1998.

19. Putri DUP. Studi Pemanfaatan Dana Bntuan Operasional Kesehatan ( BOK ) Terhadap Penurunan AKI / AKB Di Kota Bandar Lampung Tahun 2019. J Umitra. 2020;1(1):1-7.

20. Meitri Eka Susanti. Analisis Perbedaan Pelaksanaan Program Stimulasi Deteksi dan Intervensi Dini Tumbuh Kembang Balita dan Anak Prasekolah oleh Pengelola Pendidikan Anak Usia Dini di Kabupaten Bengkulu Selatan. Universitas Diponegoro; 2011.

21. Shivaraju PT, Manu G, Vinaya M SM. Evaluating the effectiveness of preand post-test model of learning in a medical school. Natl J Physiol Pharm Pharmacol. 2017;7(9):947-51. 